\title{
Leadership and Organisational Sustainability: A Study of Selected SMEs in Nigeria.
}

\author{
Esedebe, Joseph Ejime ${ }^{1}$, Ajike, Ada Kalu ${ }^{2}$, Agbor Stephen ${ }^{3}$ \& Halim, Henry Chiedu ${ }^{4}$ \\ ${ }^{1}$ Dept of Human Resource Management, Delta State Polytechnic, Ogwashi-Uku \\ ${ }^{2}$ Dept of Management, University of Nigeria, Enugu Campus \\ ${ }^{3}$ Dept of Human Resource Management, Delta State Polytechnic, Ogwashi-Uku \\ 4Dept of Estate Management and Valuation, Delta State Polytechnic, Ogwashi-Uku, Delta State \\ E-Mails: ${ }^{1}$ esedebeje@gmail.com, ${ }^{2}$ mmandeodo@yahoo.com, ${ }^{3}$ agborstephen@gmail.com
}

\begin{abstract}
Abstract: In South East Nigeria, between 1998 and 2015, about 774 businesses out of about 1,290 have gone into extinction, leaving only about 516 in existence. Thus, this study seeks to find out the relationship between leadership and SME sustainability in Nigeria. Descriptive Research design was used. The findings revealed that there was leadership innovativeness in the sector. Also, that the SME leaders show dynamism in changing business times which has boosted their risk management skill. The study recommended the implementation of the planned behavior model among SME leaders to enhance business growth and sustainability.
\end{abstract}

Keywords: Leadership, Organisation, Sustainability, SMEs and Nigeria reasoning, story-telling, debate, ability levels.

Aims Research Journal Reference Format:

Esedebe, Joseph Ejime, Ajike, Ada Kalu, Agbor Stephen \& Halim, Henry Chiedu (2018): Leadership and Organisational Sustainability: A Study of Selected SMEs in Nigeria.. Advances in Multidisciplinary \& Scientific Research Journal. Vol. 4. No.2, Pp 15-22

\section{INTRODUCTION}

\subsection{Background of the Study}

The game of business has changed dramatically over the years, particularly among small and medium enterprises (SMEs), and will continue to change due to global economic dynamics - changes in the economic system over time, especially those reflected in the behavior of the market, businesses, in the general economy. It is therefore imperative for leaders to accept and strictly follow the golden rule for leadership if they are ever to succeed in their role as leaders. The golden rule states that: "Leadership is a process of learning, not the position. Leaders are learners and it is a continued process of learning to achieve organizational goals and objectives, and for career advancement." Business leadership has been described as "the dynamic process of presenting vision, making commitment and followers and risk acceptance when facing opportunities that demand efficient resource use along with the discovery and utilization of new resources with respect to leadership vision" (Hejazi, malei \&Naciji, 2012 cited in Maladzhi, 2015). It is a relationship between those who aspire to lead and those who choose to follow; and the quality of this relationship is essential when the focus is getting things done extraordinarily.

The impact of business leadership on organizational performance is a subject that has gained so much attention, particularly in this era of increasing globalization and market competition. In the view of Matzler, Schwartz, Deutinger \& Harms (2008), leadership behaviors of the top management of small and medium enterprises (SMEs) can have a strong impact on the performance and level of innovation of the firms; therefore, as the business becomes globally competitive, SMEs need to develop new sets of vision to sustain their businesses. Competent leadership has a direct link with high innovativeness in business through leadership behaviours. This is anchored on the evidences which have leadership behaviour as a major yardstick in measuring leadership innovativeness in organizations. In this regard, leadership behaviors of the business owner or manager play a major role in providing the needed direction and clear vision, which must be shared by all the employees in the establishments (Yang, 2008)

SMEs are significant contributors to the economic fabric of the regions in which they operate. They are also impacted by the global economic context and many of them compete on a global scale. The role of SMEs is dynamic, accelerating increase in per capita income, output, employment opportunities, and enhancing regional economic balance through industrial dispersal, effective resource utilization, development of local technology, diffusion of management skill and stimulation of indigenous entrepreneurship (Adenuga, Ohuche and Ogujuba, 2004). 
In Nigeria, SMEs account for over $60 \%$ of businesses and employ about $84.02 \%$ of the total labour force and contribute $48.4 \%$ of the gross domestic product (GDP), $7.27 \%$ of the country's exports (SMEDAN, 2013). Similarly, the SME sector accounts for about 70.0 percent of industrial employment worldwide (World Bank, 1995); and has become the focus of industrial policy in recent times as revealed by the Central Bank of Nigeria (CBN Report, 1997). In the same vein, SMEs have also become the engine of economic growth and development in many nations since such industries are likely to facilitate the development of broad-based indigenous entrepreneurial culture and value added to domestic industrial production (Olorunsola, 2001). Against this backdrop, innovation is essential to their survival. Through innovation, SMEs can serve as a knob for environmental protection and creation of social value.

However, it must be emphasized that the perception and role of SME operators in the formulation and implementation of business strategies can have adverse impact on organizational performance. Consequently, a number of elements are key to SME survival in a fierce globalized environment, one of which is organized leadership. If an organization must survive in a fierce global competition, such an organization must have a high performing organization (leadership and followership). This high performing organization is reliant on some basic prerequisites which include that there must be employees, and there must be managers and leaders working there. The importance of a leader in an organization cannot be over-emphasized. In Uchenwamgbe (2013), lyioha and Ailoje (1996) pointed out that without leadership; an organization is but a module of men than machines. It is the human factors which binds a group together and motivate it towards achievement of its goals. No organizational goal is just to survive, but also to sustain its existence by improving performance. In other to meet the global competitive need of an organization, SME inclusive, there must be continual increase in performance, and the role of leadership in achieving organizational performance is critical and paramount.

\subsection{Statement of the Problem}

A growing number of businesses are at risk of closure. The Chairman of Enugu/Anambra/Ebonyi States Chapter of the Manufacturing Association of Nigeria, lamented at the $27^{\text {th }}$ Annual General Meeting of the Chapter held in 2015 that, "between 1998 and 2015, about $774(60 \%)$ businesses out of about 1,290 registered SMEs have gone into extinction, leaving only about 516 businesses (40\%) in existence. Out of which only about $129(10 \%)$ businesses can be said to be healthy and functional" (MAN, 2015). This is because the sector has been bedeviled by several factors militating against its performance, and leading to an increase in its mortality rate. These include the exogenous as well as the endogenous factors. The exogenous factors include: unfavourable and very harsh economic conditions resulting from unstable government policies; gross undercapitalisation, strained by the difficulty in accessing credits from banks and other financial institutions; inadequacies resulting from the highly dilapidated state of Infrastructural facilities; and astronomically high operating costs. While the exogenous factors refer to poor entrepreneurial and leadership skills, lack of adequate accounting skills, poor business mindset among SME operators, et cetera, he further said.

This is obviously a worrisome situation for Nigeria given that SMEs in Nigeria employ about $84.02 \%$ of the total labour force and contribute $48.4 \%$ of the gross domestic product (GDP), 7.27\% of the country's exports (SMEDAN, 2013). It is against this worrisome background that this study seeks to find out the relationship between business leadership and SME sustainability in Nigeria with particular reference to SMEs in Anambra and Abia States, Nigeria.

\subsection{Objectives of the Study}

The broad objective of this study is to assess the relationship between business leadership and SME sustainability in Nigeria. However, the specific objectives are to:

i) Assess the extent to which innovativeness affects SME profitability in Nigeria.

ii) Examine the effect of leadership dynamism on risk management of SMEs in Nigeria.

\subsection{Research Hypotheses}

Based on the objectives of the study, the following hypotheses will guide this study:

i. Leaders' innovativeness affects SME profitability in Nigeria.

i) Leadership dynamism has direct relationship with risk management of SMEs in Nigeria. 


\section{REVIEW OF RELATED LITERATURE}

\subsubsection{Leadership}

The word 'leadership' and 'leadership styles' have been used in various aspects of human endeavour with diverse definitions; according to Ogbeidi (2012), leadership is defined as a body of people who lead and direct the activities of a group towards shared goal. It refers to the ability to lead, direct and organise a group. While Cole (2002) sees leadership as a dynamic process at work in a group whereby one individual over a particular period of time, and in a particular organisational context influences the other group members to commit themselves freely to the achievement of group tasks or goals. Stogdill (1948) describes leadership style as a kind of method and capability employed by leaders aimed at realizing organizational targets and further affects all organizational activities. Sharing this view point, Fiedler (1969) opines that, leadership style refers to a kind of relationship that someone uses his rights and methods to make many people work together for a common task.

According to Ngambi (2011), cited in Jeremy et al. (2011), leadership is a process of influencing others' commitment towards realizing their full potential in achieving a value-added, shared vision, with passion and integrity. The nature of this influence is such that the members of the team cooperate with each other in order to achieve the objectives which the leader has set for each member, as well as for the group. The relationship between the leader and employee, as well as the quality of employees' performance, are significantly influenced by the leadership style adopted by the leader (Jeremy et al., 2011). Leadership style in an organization is one of the factors that play significant role in enhancing or retarding the interest and commitment of the individuals in the organization (Obiwuru et al., 2011).

Leadership is a critical management skill, involving the ability to encourage a group of people towards common goal. Leadership focuses on the development of followers and their needs. Managers exercising transformational leadership style focus on the development of value system of employees, their motivational level and moralities with the development of their skills (Ismail et al., 2009).It basically helps followers achieve their goals as they work in the organizational setting; it encourages followers to be expressive and adaptive to new and improved practices and changes in the environment (Azka et al., 2011).

According to Michael (2011) leadership has a direct cause and effect relationship upon organizations and their sustainability. Leaders determine values, culture, change tolerance and employee motivation. They shape institutional strategies including their execution and effectiveness. Leaders can appear at any level of an institution and are not exclusive to management. Successful leaders do, however, have one thing in common. They influence those around them in order to reap maximum benefit from the organization's resources, including its most vital and expensive.

\subsubsection{SME Sustainability}

The aim of an average entrepreneur (SME owners) extends beyond profit-making. Business growth and expansion constitute key objectives of SMEs. However, in a study conducted by Idemobi (2012), it was revealed that over $70 \%$ of SMEs die within five years of establishment. This means that less than $30 \%$ of SMEs can survive various business challenges. The concept of sustainability as used here is defined as the continuing commitment by businesses to behave ethically and contribute to economic development while improving the quality of life of the workforce, their families, the local and global community as well as future generations (Crals and Vereeck, 2004).

Sustainability is often considered as a possibility for large enterprises than SMEs because of variations in size and ability to overcome challenges in the business environment. In view of this, an entrepreneur must recognize and extend fair treatment to the three P's of People, Planet and Profit (Crals et al, 2004). The authors further argued that all the aspects have to be satisfied before SMEs can be labeled as sustainable. The aspect of "People" looks at how SMEs handle social and ethical issues. The kind of treatment they extend to their employees, whether it encourages social cohesion or not. Key issues like the protection of human rights, non-indulgence in fraud and corruption, the use of child labour, gender relationship and discrimination on the work floor, employees' participation in management and profits are to be considered.

In Nigeria, small and medium-sized enterprises (SMEs) play an ever-increasing role in sustainability achievement, not only for their significant contribution to the economy's GDP and GNP but job creation. This is considering the fact that more than $84 \%$ of the total labour force are employed by SMEs; more than $48 \%$ of the gross domestic product (GDP), a substantial percentage of the country's exports (SMEDAN, 2013) are contributed by the sector. This justifies the need for sustainability of the SMEs given the challenging and dynamic environment in which they operate that continue to inhibit their survival. Until recently, the fundamental prerequisite for SMEs is profitability. Through constant interaction, there has been insight on the imperativeness of the impact of sustainability in building greater profitability and long-term viability for all forms of businesses, SMEs inclusive (Horsley and Ahmed, 2011). 
There are a number of propellers driving the private sector towards greater integration of sustainability in their business models and strategies (Van der Woerd, Frans, Levy, and Begg, 2005). First, there is widespread acknowledgment that resource reduction, social inequities, and cultural breakdowns are problems that affect both individuals and organizations (Hart, 1997; Pringle, 2009). Second is the fact that the systematic failure of small businesses represents loss of jobs, breakdown in civic order and a net reduction in national output. Therefore stakeholders, from individuals to communities, public interest groups, and governments are exerting pressure to improve the management of firms through products, services and processes to ensure sustainability. SMEs are no exception since they are production units that operate in a dynamic and competitive environment.

There has been limited research on the impact of business leadership on sustainability (Sharma and Ruud, 2003), and still less is known about the practices of SMEs, From the literature we see that sustainability is contextualized as governance, increased commitment for business for social, economic, cultural and environmental interests. The Environment (Planet) is the aspect that looks at the natural environment. The Planet considers the effect and remedy of entrepreneurial activities on the natural resources. In line with the Indian adage that says that "we did not inherit the earth from our ancestors; it is on loan from our children". This implies that SMEs and in fact all businesses, must also show adequate care towards the natural environment. Profit, which is another aspect, does not relate directly to the financial results of an enterprise. It also considers the use and allocation of value added for employment, investments in machines and infrastructure. The 3p's (people, planet and profit) of sustainability also form the main sources of business risks face by SMEs. A careful recognition and handling of these three aspects would not only mean movement towards sustainability but also attempt to address the risks that threaten the achievement of enterprises' corporate objectives.

This context assumes that survival of the business. This context assumes that survival of the business is an everyday issue for the business and the main concern of the owner/entrepreneur. It is thus critical that more attention is paid to the internal aspects triggering and enabling SMEs to remain viable and therefore sustainable It has been argued that sustainability is a function of personal culture (behavior), innovativeness, knowledge and capabilities, and the motivations of owners that drive sustainability (Cronin, Smith, Gleim, Ramirez, \& Martinez, 2011; Linnenluecke \& Griffiths, 2010; Van Bommel, 2011; Visser \& Crane, 2010)

\subsection{Theories of business growth through leadership}

The long history of growth research has produced many views on what causes the growth of a firm. The analysis of firm growth as a separate phenomenon from analyzing advantages of being a particular size originates from Penrose (1959). Before her book, traditional economics had concentrated upon explaining movement from one size to another in terms of the net advantages of different sizes (O'Farrell \& hitchens, 1988). Penrose (1959) argued that there is no optimum size of a firm. She suggests that firms have a natural reason to grow: the economies of growth. The size of a firm is only a byproduct of the process of growth.

Penrose (1959) internal inducements on expansion arise when some specialized service required for the operations of the firm demands a resource. For the most part, resources are only obtainable in discrete amounts; that is to say, a bundle of services must be acquired even if only a single service should be wanted. Some capacities of the resource remain unused and unproductive. Having acquired resources for actual and contemplated operations, a firm has an incentive to use as profitably as possible the services obtainable from each unit of each type of resource acquired.

At the main limit of growth, Penrose (1959) suggests the firm's managerial ability, the rate of growth and the effectiveness in the use of a large enterprise's resources has been found to rest upon the ability and ingenuity of its administrators to build, adjust and apply its personnel and facilities to broad population, technological and income changes (Chandler, 1962). A firm cannot take advantage of all expansion opportunities if managerial ability is limited. The nature of a firm as an administrative and planning organization requires that the existing responsible officials at least know and approve the plans and operations.

Penrose (1959) based her theory on the assumption that experienced entrepreneurs have learned more capabilities to manage and to achieve their objectives than inexperienced ones. Experience may also have an effect on the entrepreneur's analysis of his environment and company potential. If an entrepreneur has a realistic view of the potential to achieve sustainable growth, he may consider the company's potential better than inexperienced ones. But the assumption does not necessarily hold true in all cases all the time. Inexperience can also bring a more biased view of potential. Therefore, there may be a link between learning and building growth oriented strategy; perception and creativity; and between an entrepreneur's previous experience and growth orientation, and these may have moderating effect of success in pursuing sustainability in the SME sector. The relationship is presented thus; 


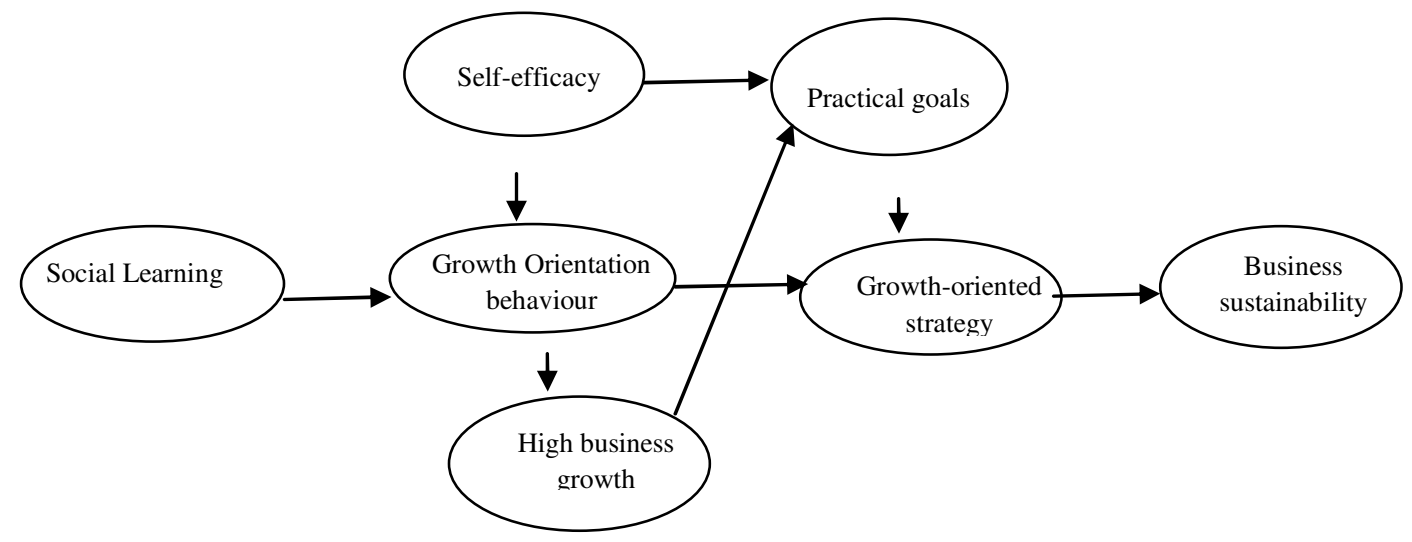

Fig. 1: synthesis on planned behavior and business sustainability.

Source: Autere, J. (2005)

\section{METHODOLOGY}

This study was conducted among 82 SMEs randomly selected for convenience from the eleven SME sub-sectors in Abia and Anambra states, South East, Nigeria. A descriptive survey design was used because of its relevance in the quantitative nature of this study. In trying to determine the nature of the relationship between business leadership and the sustainability of SMEs, self-administered questionnaire was used to collect data from 262 employees of various cadre in the selected businesses. A five-point likert scale was used. Statistical Package for Social Sciences (SPSS) was used for data analysis and statistical descriptive reporting methods were used to illustrate the degree of the relationship between the main variables of leadership and sustainability.

\section{RESULTS}

Hypothesis 1: Leaders' innovativeness affects SME profitability in Nigeria.

\section{Descriptive Statistics}

\begin{tabular}{|c|c|c|c|c|c|c|c|c|}
\hline & \multirow{2}{*}{\begin{tabular}{|l|}
$\mathrm{N}$ \\
Statistic
\end{tabular}} & \multirow{2}{*}{$\begin{array}{l}\text { Range } \\
\text { Statistic }\end{array}$} & \multirow{2}{*}{$\begin{array}{l}\text { Minimum } \\
\text { Statistic }\end{array}$} & \multirow{2}{*}{$\begin{array}{l}\text { Maximum } \\
\text { Statistic }\end{array}$} & \multicolumn{2}{|l|}{ Mean } & \multirow{2}{*}{$\begin{array}{l}\text { Std. } \\
\text { Deviation } \\
\text { Statistic }\end{array}$} & \multirow{2}{*}{$\begin{array}{l}\text { Variance } \\
\text { Statistic }\end{array}$} \\
\hline & & & & & Statistic & $\begin{array}{l}\text { Std. } \\
\text { Error }\end{array}$ & & \\
\hline $\begin{array}{l}\text { innovativeness } \\
\text { and profitability } \\
\text { Valid } \mathrm{N} \\
\text { (listwise) }\end{array}$ & $\begin{array}{l}262 \\
262 \\
262\end{array}$ & $\begin{array}{l}4.00 \\
4.00\end{array}$ & $\begin{array}{l}1.00 \\
1.00\end{array}$ & $\begin{array}{l}5.00 \\
5.00\end{array}$ & $\begin{array}{l}3.5611 \\
3.3359\end{array}$ & $\begin{array}{l}.09005 \\
.08724\end{array}$ & $\begin{array}{l}1.45760 \\
1.41210\end{array}$ & $\begin{array}{l}2.125 \\
1.994\end{array}$ \\
\hline
\end{tabular}

\section{Correlations}

\begin{tabular}{|ll|l|l|}
\hline \multicolumn{2}{|c|}{ Pearson Correlation } & Innovativeness & and profitability \\
\hline \multirow{4}{*}{ innovativeness } & Sig. (2-tailed) & 1 & .956 \\
& $\mathrm{~N}$ & & .000 \\
\multirow{4}{*}{ and } & Pearson Correlation & 262 & 262 \\
profitability & Sig. (2-tailed) & $.956^{* *}$ & 1 \\
& $\mathrm{~N}$ & .000 & \\
\hline
\end{tabular}

${ }^{\star *}$. Correlation is significant at the 0.01 level (2-tailed). 
The result indicates the Pearson Product Moment Correlation coefficient of .956. This indicated a good position that leadership innovativeness and business profitability relationship was statistical consistent. The p-value was less than 0.01 which indicates that all the tested variables were statistically significant. This shows that there is a significant relationship between leadership and SME sustainability and shows that the alternate hypotheses of this study are true. From the result of the individual variables tested in this study, $169(65 \%)$ out of 262 respondents strongly agree/agree that SME leaders create enabling creative environment of operations for their employees; while 93 (35\%) of them strongly disagree/disagree to the assertion. $153(58 \%)$ of the respondents strongly agree/agree Business owners win the trust of their employees through their show of pro-activeness in business. $94(36 \%)$ of the respondents strongly agree/agree to this claiming that the businesses owners do not exhibit proactive attitude.

Talking about show of innovativeness by the SME operators through constant product diversification and improved quality, $252(96 \%)$ respondents strongly agree/agree that SME owners are in tune, however, $10(4 \%)$ of the respondents disagreed. Using pricing strategy, $168(64 \%)$ respondents strongly agree/agree that SME owners know when and how to manipulate the prices of their products in response to changing business times, while 76 (29\%) respondents strongly disagree/disagree to this assertion. $189(72 \%)$ of the respondents strongly agree/agree that leaders of SMEs provide participatory decision making in their businesses, while $74(28 \%)$ of the respondents strongly disagree/disagree.

Hypothesis 2: leadership dynamism has direct relationship with risk management of SMEs in Nigeria.

\section{Descriptive Statistics}

\begin{tabular}{|l|l|l|l|}
\hline & Mean & Std. Deviation & $\mathrm{N}$ \\
\hline Dynamism & 3.4924 & 1.32394 & 262 \\
risk management & 2.8435 & 1.34845 & 262 \\
\hline
\end{tabular}

\section{Correlations}

\begin{tabular}{|ll|l|l|}
\hline & & dynamism & risk management \\
\hline \multirow{2}{*}{ Dynamism } & Pearson Correlation & 1 & .844 \\
& Sig. (2-tailed) & & .000 \\
& $\mathrm{~N}$ & 262 & 262 \\
risk management & Pearson Correlation & .844 & 1 \\
& Sig. (2-tailed) & .000 & \\
\hline
\end{tabular}

${ }^{* *}$. Correlation is significant at the 0.01 level (2-tailed).

The result indicates Pearson Product Moment Correlation coefficient of .844. This indicated a good position that leadership dynamism and risk management relationship was statistically consistent. The p-value was less than 0.01 which indicates that all the tested variables were statistically significant. This shows that there is a significant relationship between leadership and SME sustainability and shows that the alternate hypothesis is true.

\section{CONCLUSION}

This study set out to ascertain the relationship between leadership behavior and the achievement of sustainability among SMEs in Abia and Anambra States of Nigeria. The response from most of the respondents evaluating their leaders was not satisfactory, though positive. This is because most of the respondents who were employees responded in favour of their leaders for obvious reasons. SME leaders on the other hand, rated themselves high in most of the variables, accounting for the gap between the study and the reality in Nigeria considering the rate of SME failures in Nigeria.

From the literature reviewed in this study, leadership role has to do with the attitude and behavior built from their business mindset which is developed through the interaction of the endogenous as well as the exogenous factors of behavior. These factors range from previous experiences, perception, social capital, risk management skill, as well as social learning, among other things. The planned behavior and business sustainability model can be very helpful in improving the state of innovativeness of SME leaders and in turn sustain businesses. According to the model, leadership innovativeness is shown through the exhibition of self efficacy which is reflected in the attainable goals set for the business. This self efficacy is built through social learning orientation, which equips the leader in the formulation of growth orientation strategies for the business. All these when achieved will translate to business growth and sustainability. 


\section{REFERENCES}

1. Adenuga, A.O., Ohuche, F.K., and Ogujiuba, K.K. (2004). Credit Availability to Small and Medium Scale Enterprises in Nigeria: Importance of New Capital Base for Banks. Bullion Publication of CBN, 28, pp. 51-68. (No 4)

2. Ajike, A.K. (2017) Assessment of Entrepreneurial Mindset on the sustainability of SMEs in Nigeria. A PhD Thesis in Management, (Unpublished) University of Nigeria, Enugu.

3. Autere, J. (2005). Is entrepreneurship learned? Influence of mental models on growth orientation, growth strategy, and business growth. Academy of Management 2000 conference, Toronto; $4-9$.

4. Azka .G, Tahir. M, Aslam. M \& Syed.T (2011). Transformational leadership, employee engagement and performance: mediating effect of psychological ownership. African Journal of Business Management, .5(17), 7391-7403.

5. Central Bank of Nigeria (CBN). In: Annual Report 1997

6. Chandler, A.C. (1962). Strategy and Structure: Chapters in the History of the American Industrial enterprises. Nineteenth printing 1995, The MIT Press, Cambridge, MA.

7. Crals, E., \& Vereeck, L. (2004) Sustainable Entrepreneurship in SMEs: Theory and Practice. Poster presented at the 3rd Global Conference on Environmental Justice and Global Citizenship, Copenhangen, Denmark, 12th 14th February

8. Hart, S. 1997, "Beyond greening: strategies for a sustainable world", Harvard Business Review, No. 75, pp. 6676.

9. Hejazi, S.A.M, Malei, M.M. \& Naeiji, M.J. (2012) "Designing a Scale for Measuring Entrepreneurial Leadership in SMEs," International Conference on Economics, Marketing and Management, IPEDR, vol. 28, pp. 71-77.

10. Idemobi, E.I. (2012) The problem of sustaining the growth of Small and Medium Enterprises in a typical SubSaharan African Context. African Journal of Social Sciences, 2, 15-2

11. Ismail A, Halim F. A, Munna D. N, Abdullah A, Shminan A. S, Muda A. L. (2009). The mediating effect of empowerment in the relationship between transformational leadership and service quality. J. Bus. Manage., 4(4), 3-12.

12. Jeremy .M, Melinde .C \& Ciller V. (2012). Perceived leadership style and employee participation in a manufacturing company in the democratic republic of Congo, African journal of business management, .6(15), 5389-5398.

13. Linnenluecke, M. K., \& Griffiths, A. (2010), “Corporate sustainability and organizational culture”, Journal of world business, Vol.45 No.4, pp. 357-369.

14. Maladzhi, R.W. (2015) "Impact of Risk-taking leadership on Organisational performance and sustainability in SMEs." A Conference Paper. Research Gate.

15. Matzler, K., Schwarz, E., Deutinger, N. and Harms, R. (2008) Relationship between Transformational Leadership,

16. Product Innovation and Performance in SMEs. Journal of Small Business and Entrepreneurship, 139-152. http://dx.doi.org/10.1080/08276331.2008.10593418

17. Michael. A. (2010). Leadership style and organizational impact. Retrieved from: http/ www.ala- apa.org.

18. Ngambi H. C. (2011). Rare total leadership: Leading with the heart and hands. Juta, Cape Town.

19. Obiwuru .T, Okwu. A, Akpa. V \& Nwankere .I (2011). Effects of leadership style on organiszational performance: A survey of selected small scale enterprises in Ikosi - Ketu Council development area of Lagos State, Nigeria. Australian journal of business and management research 1(7).

20. Olorunsola, J.A. (2001). Industrial Financing in Nigeria: A Review of Institutional Arrangement. CBN Economic and Financial Review, 39, pp. 40-72 (Vol.1).

21. O'Farrell, P.N. and Hitchens, D.M.W.N. (1988). Alternative theories of small firm growth: A critical review. Environment and Planning, 20: $1365-1383$.

22. Ojokuku, R.M., Odetayo, T.A. \& Sajuyigbe, A.S. (2012). Impact of Leadership style on Organisational performance: A case study of Nigerian Banks. American Journal of Business and Management, vol. 1(4) $202-$ 207.

23. Penrose, E. (First Ed. 1959). The theory of the growth of the firm. 3rd ed. (1995) Oxford: Oxford University Press.

24. Sharma. S. and Ruud A. (2003), "On the path to sustainability: integrating social dimensions into the research and practice of environmental management." Business Strategy and the Environment, Vol.12 No.4, pp. 205214 
25. Small and Medium Enterprises Development Agency of Nigeria (SMEDAN)(2013). National Policy on Micro, Small and Medium Enterprises. Federal Republic of Nigeria, SMEDAN, Abuja, Nigeria, January.

26. Van Bommel, H. W. (2011), "A conceptual framework for analyzing sustainability strategies in industrial supply networks from an innovation perspective", Journal of Cleaner Production, Vol.19 No.8, pp.895-904.

27. Van der Woerd, F. Levy. D.L and Begg.K. (2005), "The business of climate change: corporate responses to Kyoto", Greenleaf Publishing, London, UK.

28. Visser, W., \& Crane, A. (2010), "Corporate sustainability and the individual: understanding what drives sustainability professionals as change agents", Available at http:www.ssrn.com: 1559087.

29. World Bank (1995). Advancing Social Development. Washington D.C The International Bank for Reconstruction and development. World Economic Forum In: Global Competitive Report 2008-2009

30. Yang, C.W. (2008) The Relationships among Leadership Styles, Entrepreneurial Orientation, and Business Performance. Managing Global Transitions, 6, 257-275.

31. Yanney, J.P. (2014) Business strategy and Leadership style: Impact on Organisational Performance in the Manufacturing Sector of Ghana. American Journal of Industrial and Business Management 767 - 775. 